Iatsenko A. Mishchenko A., Kornilovych B.

\title{
INVESTIGATION OF THERMAL STABILITY, OPTICAL PROPERTIES, PHASE AND CHEMICAL COMPOSITION OF TRANSPARENT CONDUCTIVE TIN OXIDE FILMS DEPOSITED BY PYROLYTIC METHOD ON SILICA FLOAT GLASS
}

\begin{abstract}
Об'єктом дослідження є прозоре електропровідне покриття на основі допованого фтором оксиду олова, осадженого на силікатному флоат-склі піролітичним методом. Однак, як в процесі виготовлення такого покриття, так і в процесі його експлуатацї, спостерігається деградація його електропровідних властивостей. Це може бути наслідком зміни структури покриття під дією впливу деяких технологічних та експлуатаційних факторів, а саме: температури процесу, часу витримки, газового середовища в процесі нанесення та експлуатацї прозорого електропровідного покриття. Проведені дослідження підтвердили значне підвищення електропровідності. Вони також виявили незначне зниження світлопропускання прозорих оксидно-олов'яних плівок, отриманих з введенням фториду амонію у якості допанту при піролізі $1 \mathrm{M}$ спиртових розчинів хлоридів $\mathrm{Sn}^{2+}$ та $\mathrm{Sn}^{4+}$, що широко застосовуються як прекурсори для тримання таких покриттів. Так, при співвідношенні $\mathrm{Sn}^{4+} / \mathrm{F}=10$ у робочих розчинах зафіксовано мінімум питомого

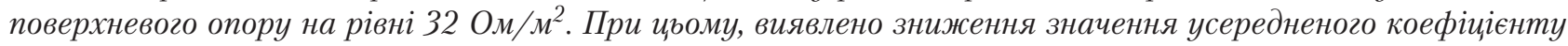
світлопропускання в оптичному діапазоні довжин хвиль 0,2-6,0 мкм на 51 \%, а у його видимій частині (0,4-0,8 мкм) на $11 \%$. Показано, що суттєвим фактором збільшення значень електричного опору як в технологічному процесі, так і під час експлуатаційних впливів є термічна деградація покриття. Отримані результати свідчать, що повторне нагрівання до температур понад $450{ }^{\circ} \mathrm{C}$ призводить до появи явища термічної деструкиї електропровідних властивостей покриття. Так, протягом 1-годинної витримки за температури $550^{\circ} \mathrm{C}$ збільшення питомого поверхневого опору збільшується в 2 рази $і$ фіксується на рівні $68 \mathrm{Oм} / \mathrm{s}^{2}$ після повного охолодження. Повторні цикли нагріву з вказаними параметрами призводять до значно меншого впливу, що може свідчити про стабілізащію процесів, які мають місце при термічній деструкції електропровідного покриття.
\end{abstract}

Ключові слова: прозорі електропровідні покриття, флоат-скло, оксид олова допований фтором, термічна стабільність.

\section{Introduction}

Transparent conductive coatings based on Sn, In, Zn and $\mathrm{W}$ oxides are widely used in the manufacture of components and products for the needs of science and technology. And also find application in electrodes, current drives, heating elements of technical ceramics and special glass [1-3]. Among the number of methods that are used to obtain such coatings, the simple, hardwarefriendly method of pyrolytic deposition of an electrically conductive oxide-metal coating, which has found application in practice [4-6], is distinguished. It is attracted to glass production for the mass production of flat float glass with a transparent electrically conductive coating for the manufacture of energy-saving windows, transport viewing and special glass with electric heating. The main guarantee of a consistently high quality manufacturing of such glass is strict adherence to the process parameters. And its operational characteristics depend on a number of factors with which these products are encountered when used for their intended purpose, namely: mechanical, chemical and thermal effects on the surface of the product. The most interesting in this sense is the thermal effect, since protection from the first two factors is achieved by the usual orientation of the side of the glass with an electrically conductive coating on the opposite side with respect to the direction of their action. The thermal stability of such a coating may depend both on temperature and on the cyclic heating-cooling. This, in turn, will determine the life of the product in the given parameters and a fundamentally important factor for the manufacture of high-quality durable products.

Such a coating in the form of thin films is most often obtained using the pyrolytic method using precursors of 
alcohol solutions of tin compounds [1, 2, 6]. To improve the conductivity, the films obtained are modified by introducing alloying elements, the main of which are Sb, In, and F [7-9]. The latter exhibits the greatest influence on the change in the electroconducting properties of $\mathrm{SnO}_{2}$ films, but leads to undesirable consequences, which are manifested in the loss of transparency of the films as a result of the chemical action of $\mathrm{F}$ on the structure of the surface layers of silica glass $[10,11]$.

Therefore, it is relevant to study thermal stability, namely, changes in the electrical resistance of transparent oxide-tin conductive films deposited by the pyrolytic method on silica float glass, by studying changes in their phase and chemical composition under various conditions.

\section{The object of research and its technological audit}

The object of research is a transparent conductive coating based on tin oxide doped with fluorine deposited on silica float glass using the pyrolytic method.

Among the existing transparent conductive oxides doped with various elements, tin oxide is the most conductive, chemically, abrasive, and thermally stable oxide, which determines its widespread use as a transparent conductor. However, a technological audit of the object of research reveals insufficient knowledge of the issue of thermal stability of coatings based on this oxide. This makes it difficult to understand the processes that occur during the synthesis and operation of such electrically conductive coatings and which lead to thermal degradation of the coating, which results in a gradual increase in the values of electrical resistivity and the loss of operational parameters of electrically conductive films.

\section{The aim and objectives of research}

The aim of research is studying the influence of synthesis technological parameters and operation parameters of transparent electrically conductive films based on fluorine doped tin oxide obtained by the pyrolytic method on silica float glass on its electrical conductivity and transparency.

To achieve this aim, the following objectives are identified:

1. To study the effect of fluorine as an alloying element on the spectral characteristics and electrical resistivity of conductive $\mathrm{SnO}_{2}$ films.

2. To determine the effect of temperature and thermal exposure on the electrical resistance of $\mathrm{SnO}_{2}$ electrically conductive films.

3. To study the dependences of the phase composition variation on the exposure conditions of $\mathrm{SnO}_{2}$ electrically conductive films to understand the phenomenon of «thermal degradation» of these electrically conductive coatings.

\section{Research of existing solutions of the peoblem}

Tin dioxide is a wide-gap $n$-type semiconductor with a band gap of $3.87-4.3 \mathrm{eV}$, the electrical conductivity of which substantially depends on the degree of ordering, the type and concentration of structural defects in its crystal lattice. For thin films, the electrical conductivity additionally depends on the size, shape of the clusters (grains), the nature of their mutual arrangement, and the degree of amorphism of the coating structure $[12,13]$. The structure of the crystalline gradation of $\mathrm{SnO}_{2}$ for the stoichiometric ratio $\mathrm{O} / \mathrm{Sn}=2$ is described by a rutile-type hexagonal lattice. To reduce the values of the forbidden zone in it and increase the concentration of structural defects, the properties of tin oxide responsible for the conductor and its various elements are responsible for it. Thus, the introduction of $\mathrm{In}$ and $\mathrm{Sb}$, aimed at breaking the uniformity of the $\mathrm{SnO}_{2}$ structure behind tin ( $p$-type conductivity), and the introduction of $\mathrm{F}^{-}-$by oxygen ( $n$-type). The most effective in this sense is doping of the $\mathrm{SnO}_{2}$ structure with fluorine $[10,13]$.

The technological process of pyrolytic deposition of such oxide-metal films is one of the most and differs in simplicity in implementation [2,6]. Films obtained with its help have high transparency in the visible part of the optical wavelength range $\left(T_{\lambda} \geq 90 \%\right)$ at low surface electrical resistance $\left(\rho \leq 10^{2} \mathrm{Ohm} / \mathrm{m}^{2}\right)$. It is known that the electrical conductivity of transparent films depends not only on the dopant ion, but also on the temperature of the deposition process. The redox properties of the atmosphere both during the deposition process and during operation, and the thermal mode of operation of such films [12, 13], significantly affect the conductivity of the coating. So, the authors of this work were not able to find a systematic study on this topic, although it was possible to partially generalize such data from different studies. Upon reaching high temperatures, the change in electrical resistance becomes irreversible and is described by the phenomenon of «thermal degradation» of a transparent electrically conductive coating. For $\mathrm{SnO}_{2}$ films doped with in, this process becomes irreversible even at temperatures higher than $120-140{ }^{\circ} \mathrm{C}[7,14]$, and occurs in several stages. When these temperatures are reached, the first decomposition stage is observed, which manifests itself in a decrease in electrical conductivity. The final destruction occurs at temperatures of $360-400{ }^{\circ} \mathrm{C}$ and leads to the destruction of the film structure with an almost complete loss of electrical conductivity. Films doped with Sb have a thermal stability limit of $150-200{ }^{\circ} \mathrm{C}[8,13]$, above which the phenomena described above are observed. The highest limit of thermal stability is observed in transparent electrically conductive coatings based on tin oxide doped with $\mathrm{F}^{-}$with a limit to the onset of thermal destruction from $400-450{ }^{\circ} \mathrm{C}[13,15,16]$. Thus, it is $\mathrm{SnO}_{2}$ films doped with fluorine, which combine both high electrical conductivity and the greatest stability considered above, are characterized by thermal stability.

The processes of thermal destruction, most likely associated with changes in the structure of the crystalline lattice, the redistribution of defects in the structure, and the alignment of the $\mathrm{Me} / \mathrm{O}$ ratio towards the stoichiometric [17], are of scientific interest and require detailed study.

\section{Methods of research}

The films were created by the pyrolytic method using a NE-C28P compressor nebulizer (OMRON, Japan) by applying thin (Mass Median Aerodynamic Diameter $=3 \mu \mathrm{m}$ ) aerosols of $1 \mathrm{M}$ water-alcohol solutions of $\mathrm{SnCl}_{2} \cdot 2 \mathrm{H}_{2} \mathrm{O}$ and $\mathrm{SnCl}_{4} \cdot 5 \mathrm{H}_{2} \mathrm{O}$ to heated silica float samples glass size $20 \times 20 \times 2 \mathrm{~mm}$. Sheet sodium-calcium-aluminum-silica glass made by the float method was used in the work.

The temperature of the samples was varied in the range $450-550{ }^{\circ} \mathrm{C}$. Doping of $\mathrm{SnO}_{2}$ films was carried out 
by introducing into the working solutions $\mathrm{NH}_{4} \mathrm{~F}$ in the amount necessary to create a $\mathrm{Sn} / \mathrm{F}$ ratio from 1 to 100 . Control solutions contained $\mathrm{NH}_{4} \mathrm{~F}$.

Optical properties were evaluated visually for transparency of the films, the presence of defects associated with the corrosion effect of $\mathrm{F}^{-}$on the glass surface. The light transmission of the coated glass samples was investigated using an SF-46 spectrophotometer (LOMO, Russia) in the ultraviolet, visible and near infrared (IR) parts of the optical wavelength range $(\lambda=0.2-1.1 \mathrm{~nm})$. And IR-Fourier was investigated using the FSM 1202M spectrometer (Infraspectrum, Russia) in the infrared part $(\lambda=1.2-6 \mu \mathrm{m})$.

The electrical resistance of the samples was determined by a two-probe DC ohmmeter.

To determine the phase composition of a thin film formed as a result of pyrolysis of precursor solutions on the glass surface, a DRON-3 diffractometer (Burevestnik, Russia) was used, equipped with an X-ray tube with a copper anode, a graphite monochromator, and a computer scanning system.

The chemical composition of glass samples and a transparent electrically conductive coating was controlled using an Expert 3L energy-dispersive X-ray fluorescence analyzer (INAM, Ukraine) in a helium atmosphere.

\section{Research results}

It is revealed that the region of maximum electrical conductivity lies at the boundary of the ratios $\mathrm{Sn}^{2+} / \mathrm{F}=7$ and $\mathrm{Sn}^{4+} / \mathrm{F}=10$. A larger amount of $\mathrm{F}$ leads to a noticeable decrease in the transparency and uniformity of the films and, as a consequence, to a sharp decrease in their electrical conductivity. At lower ratios, the dependence of the electrical conductivity of $\mathrm{SnO}_{2}$ films doped with fluorine naturally depends on the $\mathrm{F}^{-}$content in the working solution and decreases exponentially. Films with a high $\mathrm{F}$ content have significantly less light transmission both in the visible and in the IR wavelength range (Fig. 1).

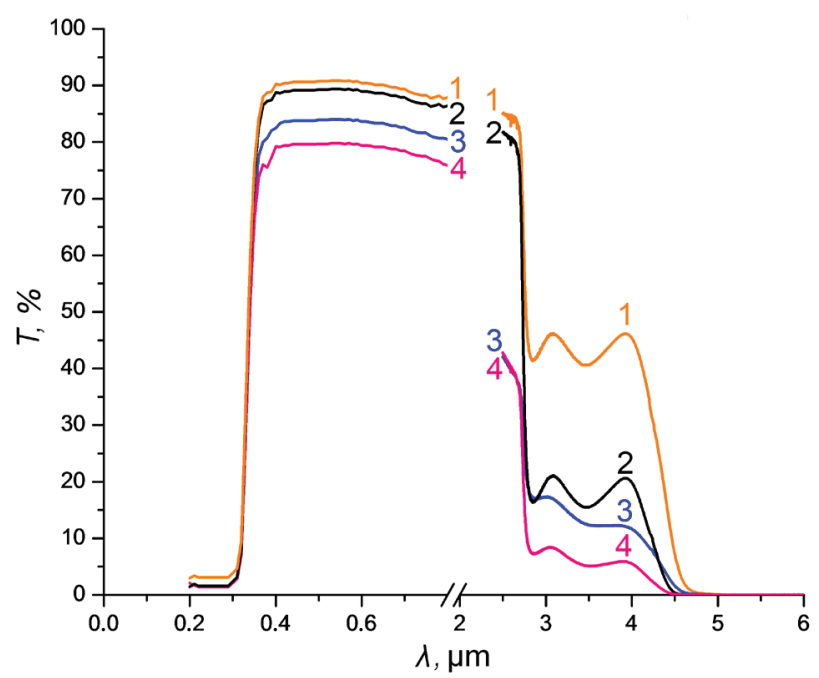

Fig. 1. The spectral characteristics of glass samples with an electrically conductive coating obtained by pyrolysis of $1 \mathrm{M}$ alcohol solutions of compounds: $1-5 n^{2+} ; 2-5 n^{2+}+F ; 3-5 n^{4+} ; 4-5 n^{4+}+F^{-}$

In this case, the decrease in light transmission in the IR region from $2 \mu \mathrm{m}$ to $4 \mu \mathrm{m}$ is more significant than in the range from 0.4 to $0.8 \mu \mathrm{m}$. It was experimentally confirmed that the resistivity of $\mathrm{SnO}_{2}$ films obtained from $\mathrm{Sn}^{4+} / \mathrm{F}$ working solutions is $2-4$ times lower than that of films obtained from $\mathrm{Sn}^{2+} / \mathrm{F}$ solutions, ceteris paribus. This is evidenced by the results presented in Fig. 2.

For $\mathrm{SnO}_{2}$ films obtained from $\mathrm{Sn}^{4+} / \mathrm{F}$ working solutions with a molar ratio $\mathrm{Sn} / \mathrm{F}=10$, thermal stability was studied by exposing samples with a freshly coated coating in the temperature range $450-550{ }^{\circ} \mathrm{C}$ for $0-10 \mathrm{~min}$ (Fig. 3).

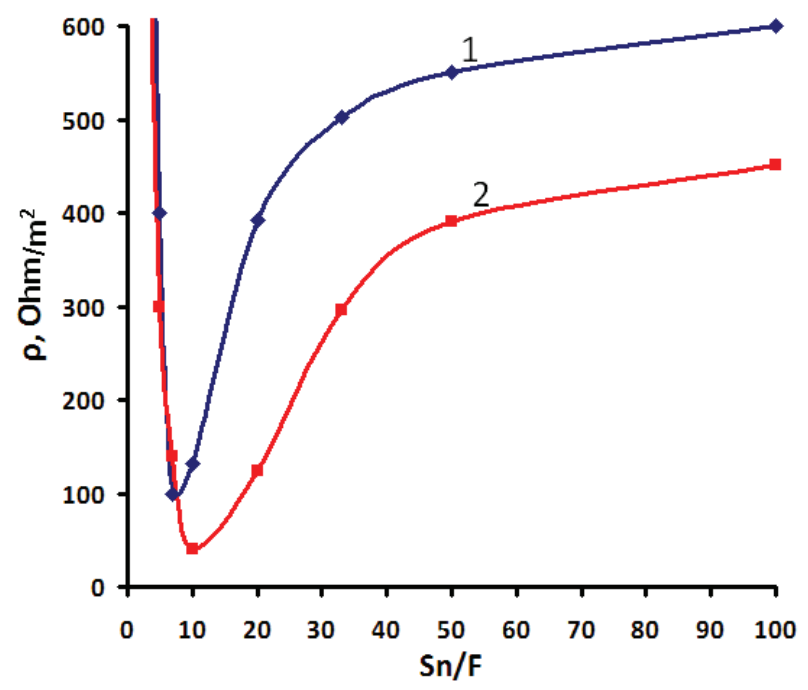

Fig. 2. The dependence of the specific surface resistance of the samples on the fluorine content in $1 \mathrm{M}$ alcohol solutions of the compounds: $1-5 n^{2+} ; 2-5 n^{4+}$

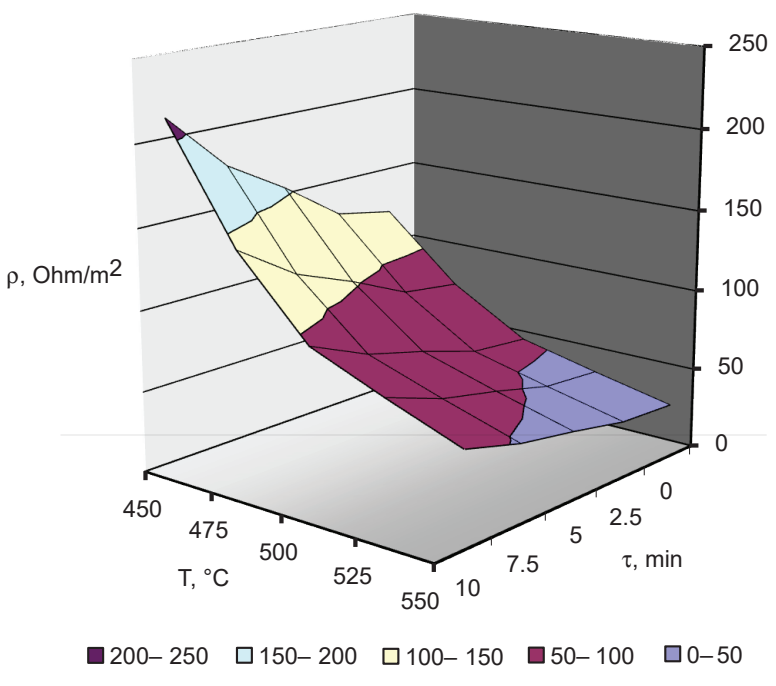

Fig. 3. The dependence of the specific surface resistance of the samples on the pyrolysis temperature and exposure time

Additionally, to determine the causes of such changes, an X-ray phase study (Fig. 4) and an energy-dispersive $\mathrm{X}$-ray fluorescence elemental analysis (Table 1) of the studied samples were used.

The result of the study of the thermal degradation of the electrically conductive coating revealed a significant increase in the specific surface resistance of the samples, which were maintained in an oxidizing atmosphere of air at temperatures above $400{ }^{\circ} \mathrm{C}$ even with short exposures (Table 2). 


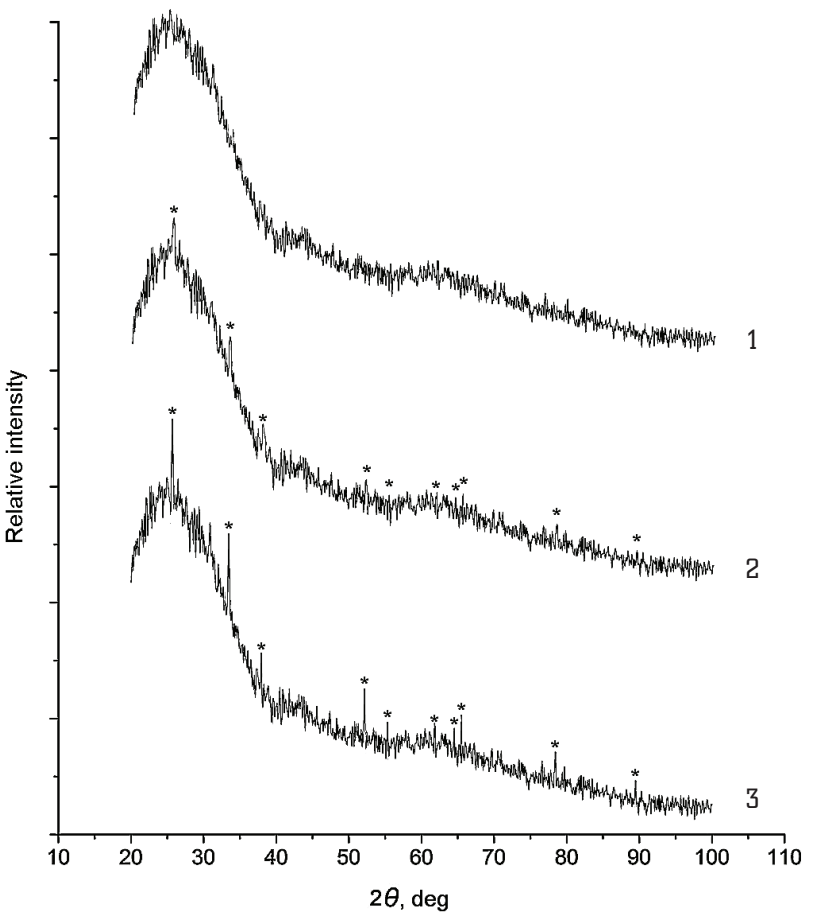

Fig. 4. Diffractograms:

1 - source glass; 2 - coated glass; 3 - glass with thermally degraded coating
The obtained data indicate the course of the formation of the crystalline phase of cassiterite $\mathrm{SnO}_{2}$ with a tetragonal structure of the crystalline lattices by the rutile type. Moreover, a decrease in the electrical conductivity of the coating is most likely a consequence of thermal structure-forming processes, as evidenced by the narrowing of characteristic peaks and an increase in their intensity in diffractogram 3 (Fig. 4). As a result of this, partial ordering of the $\mathrm{SnO}_{2}$ lattice occurs with compensation of defects that are responsible for electrical conductivity, and the replacement of the built-in fluorine by oxygen from the air atmosphere. This is evidenced by a decrease in its concentration in the coating from 0.9 to $0.3 \%$ of the mass.

\section{SWOT analysis of research results}

Strengths. The main advantages of transparent electroconductive metal oxide films obtained by the pyrolytic method using Sn and F compounds are:

- cheapness;

- ease of industrial implementation of the pyrolytic deposition method;

- high (in comparison with other electrically conductive metal oxide films) thermal stability, both in a neutral gas medium and in air;

- high transmittance in the visible part of the optical wavelength range.

Table 1

The chemical composition of the samples

\begin{tabular}{|c|c|c|c|c|c|c|c|c|c|c|c|}
\hline \multirow{2}{*}{ Sample } & \multicolumn{11}{|c|}{ Mass content, \% } \\
\hline & $\mathrm{SiO}_{2}$ & $\mathrm{Al}_{2} \mathrm{O}_{3}$ & $\mathrm{CaO}$ & $\mathrm{MgO}$ & $\mathrm{Na}_{2} \mathrm{O}$ & $50_{3}$ & $\mathrm{Fe}_{2} \mathrm{O}_{3}$ & $\mathrm{SnO}_{2}$ & $\mathrm{~F}$ & $\mathrm{Cl}$ & $\Sigma$ \\
\hline Original float glass & 72.6 & 1.4 & 8.2 & 3.0 & 14.1 & 0.4 & $\leq 0.1$ & 0.2 & $\leq 0.1$ & $\leq 0.1$ & 100.0 \\
\hline Coated glass & 72.4 & 1.4 & 8.2 & 3.0 & 14.0 & 0.4 & $\leq 0.1$ & 0.5 & $\leq 0.1$ & $\leq 0.1$ & 100.0 \\
\hline Unexposed coating & $\leq 0.1$ & $\leq 0.1$ & $\leq 0.1$ & $\leq 0.1$ & $\leq 0.1$ & $\leq 0.1$ & $\leq 0.1$ & 98.8 & 0.9 & 0.2 & 100.0 \\
\hline Exposed* in an atmosphere $\mathrm{N}_{2}$ & $\leq 0.1$ & $\leq 0.1$ & $\leq 0.1$ & $\leq 0.1$ & $\leq 0.1$ & $\leq 0.1$ & $\leq 0.1$ & 98.9 & 0.7 & 0.2 & 100.0 \\
\hline Exposed ${ }^{*}$ in an atmosphere $\mathrm{N}_{2}+\mathrm{O}_{2}$ & $\leq 0.1$ & $\leq 0.1$ & $\leq 0.1$ & $\leq 0.1$ & $\leq 0.1$ & $\leq 0.1$ & $\leq 0.1$ & 99.5 & 0.3 & $\leq 0.1$ & 100.0 \\
\hline
\end{tabular}

Note: ${ }^{*}$ - the exposure of the samples to study the phenomenon of thermal degradation of the conductive properties of the coating was carried out at $550{ }^{\circ} \mathrm{C}$ for 1 hour

Table 2

Specific surface resistance $\rho\left(0 \mathrm{hm} / \mathrm{m}^{2}\right)$ of the investigated samples

\begin{tabular}{|c|c|c|c|c|c|c|}
\hline \multirow{2}{*}{$T,{ }^{\circ} \mathrm{C}$} & \multirow{2}{*}{ Atmosphere } & \multicolumn{5}{|c|}{ Exposure time, min } \\
\hline & & 10 & 20 & 30 & 45 & 60 \\
\hline \multirow{2}{*}{100} & $\mathrm{~N}_{2}$ & 32 & 32 & 32 & 32 & 32 \\
\hline & $\mathrm{N}_{2}+\mathrm{O}_{2}$ & 32 & 32 & 32 & 32 & 32 \\
\hline \multirow{2}{*}{200} & $\mathrm{~N}_{2}$ & 32 & 32 & 32 & 32 & 32 \\
\hline & $\mathrm{N}_{2}+\mathrm{D}_{2}$ & 32 & 32 & 32 & 32 & 32 \\
\hline \multirow{2}{*}{300} & $\mathrm{~N}_{2}$ & 32 & 32 & 32 & 32 & 32 \\
\hline & $\mathrm{N}_{2}+\mathrm{O}_{2}$ & 32 & 32 & 33 & 33 & 33 \\
\hline \multirow{2}{*}{400} & $\mathrm{~N}_{2}$ & 32 & 32 & 33 & 33 & 33 \\
\hline & $\mathrm{N}_{2}+\mathrm{O}_{2}$ & 33 & 34 & 34 & 35 & 35 \\
\hline \multirow{2}{*}{500} & $\mathrm{~N}_{2}$ & 33 & 33 & 34 & 34 & 35 \\
\hline & $\mathrm{N}_{2}+\mathrm{O}_{2}$ & 37 & 42 & 45 & 48 & 50 \\
\hline \multirow{2}{*}{550} & $\mathrm{~N}_{2}$ & 35 & 36 & 36 & 37 & 37 \\
\hline & $\mathrm{N}_{2}+\mathrm{O}_{2}$ & 68 & 73 & 77 & 80 & 82 \\
\hline
\end{tabular}


Weaknesses. The use of the pyrolytic method leads to increased requirements for labor protection, control of the air parameters of the working area in production and the additional installation of filtration equipment in the ventilation system.

Opportunities. Promising areas of further research are:

- comparative studies of the thermal stability of other transparent conductive coatings and comparison of their parameters with the data obtained;

- search and study of the possibility of using other tin precursors to obtain transparent electrically conductive films; - study of the processes of adhesion of a transparent electrically conductive film to the surface of silica glass; - creation of multilayer fields of functional coatings on the glass surface.

Threats. The development of effective methods of nanostructured engineering of materials creates a fairly strong competitive environment in the production of functional film coatings.

\section{Conclusions}

1. As a result of the study, it is found that the modification of $\mathrm{SnO}_{2}$ films by fluorine not only increases their electrical conductivity, but also reduces the overall light transmission of the films both in the visible and in the IR wavelength range. The decrease in the resistivity of these films is more pronounced when using water-alcohol solutions based on $\mathrm{Sn}^{4+}$ compounds, both with and without $\mathrm{NH}_{4} \mathrm{~F}$. It is shown that the maximum possible ratio for obtaining high-quality transparent $\mathrm{SnO}_{2}$ films is $\mathrm{Sn}^{2+} / \mathrm{F}=7$, and $\mathrm{Sn}^{4+} / \mathrm{F}=10$. It is established that the decrease in the transmittance of films in the IR part of the spectrum for $\mathrm{Sn}^{4+}+\mathrm{F}$ is less than for $\mathrm{Sn}^{2+}+\mathrm{F}$.

2. It is revealed that thermal stability, as well as the specific surface resistance of films obtained from solutions based on $\mathrm{Sn}^{4+} / \mathrm{F}$, significantly depends on temperature and time. So, the lowest resistivity can be achieved at high temperatures and a short residence time of the films in these conditions.

3. A possible reason for the «thermal degradation» of the electrically conductive ability of the films should be considered attempts by the Sn-O system to be ordered in accordance with the stoichiometric ratio $\mathrm{O} / \mathrm{Sn}=2$, the deviation from which in the partially amorphous structure of the electrically conductive films leads to the appearance of semiconductor properties, which are usually characterized by $n$-type. It is found that thermal degradation of the electrically conductive properties is associated with the improvement of the structure and crystallization processes in $\mathrm{SnO}_{2}$ films and a decrease in the content of the adducting $\mathrm{F}^{-}$ion.

Based on the obtained results, it is possible to recommend the synthesis of electrically conductive films on a sheet of sodium-calcium-aluminosilica float glass at temperatures close to its annealing temperature $T_{g}=560{ }^{\circ} \mathrm{C}$, with a minimum thermal exposure of the resulting coating. It is not necessary to use the obtained films at temperatures below $400{ }^{\circ} \mathrm{C}$ in an oxidizing atmosphere or up to $500{ }^{\circ} \mathrm{C}$ in an inert atmosphere.

\section{Acknowledgments}

The authors would like to express sincere thanks to Dr. T. Tomila and Dr. O. Bykov from Frantsevich Institute for Problems of Materials Science of NAS of Ukraine for IR spectroscopy and XRD results, respectively.

\section{References}

1. Bach, H., Krause, D. (Eds.) (2003). Thin films on glass. Springer Science $\mathcal{E}$ Business Media, 436. doi: http://doi.org/10.1007/ 978-3-662-03475-0

2. Minami, T. (2005). Transparent conducting oxide semiconductors for transparent electrodes. Semiconductor Science and Technology, 20 (4), S35-S44. doi: http://doi.org/10.1088/02681242/20/4/004

3. Mattox, D. M. (2010). Handbook of physical vapor deposition (PVD) processing. William Andrew, 732. doi: http://doi.org/ 10.1016/c2009-0-18800-1

4. Van Mol, A. M. B., Chae, Y., McDaniel, A. H., Allendorf, M. D. (2006). Chemical vapor deposition of tin oxide: Fundamentals and applications. Thin Solid Films, 502 (1-2), 72-78. doi: http:// doi.org/10.1016/j.tsf.2005.07.247

5. Lincot, D., Hodes, G. (2006). Chemical solution deposition of semiconducting and non-metallic films. The Electrochemical Society, 234.

6. Wasa, K., Kanno, I., Kotera, H. (Eds.) (2012). Handbook of sputter deposition technology: fundamentals and applications for functional thin films, nano-materials and MEMS. William Andrew, 660.

7. Manoj, P. K., Joseph, B., Vaidyan, V. K., Amma, D. S. D. (2007). Preparation and characterization of indium-doped tin oxide thin films. Ceramics International, 33 (2), 273-278. doi: http://doi.org/ 10.1016/j.ceramint.2005.09.016

8. Elangovan, E., Ramamurthi, K. (2005). A study on low costhigh conducting fluorine and antimony-doped tin oxide thin films. Applied Surface Science, 249 (1-4), 183-196. doi: http:// doi.org/10.1016/j.apsusc.2004.11.074

9. Moholkar, A. V., Pawar, S. M., Rajpure, K. Y., Bhosale, C. H., Kim, J. H. (2009). Effect of fluorine doping on highly transparent conductive spray deposited nanocrystalline tin oxide thin films. Applied Surface Science, 255 (23), 9358-9364. doi: http:// doi.org/10.1016/j.apsusc.2009.07.035

10. Pavlushkin, N. M. (1983). Khimicheskaia tekhnologiia stekla $i$ sitallov. Moscow: Stroiizdat, 432.

11. Saito, K., Ikushima, A. J. (2002). Effects of fluorine on structure, structural relaxation, and absorption edge in silica glass. Journal of Applied Physics, 91 (8), 4886-4890. doi: http://doi.org/ 10.1063/1.1459102

12. Li, J., Wang, L., Liu, J., Evmenenko, G., Dutta, P., Marks, T. J. (2008). Characterization of Transparent Conducting Oxide Surfaces Using Self-Assembled Electroactive Monolayers. Langmuir, 24 (11), 5755-5765. doi: http://doi.org/10.1021/la704038g

13. Coutts, T. J., Young, D. L., Li, X. (2000). Characterization of Transparent Conducting Oxides. MRS Bulletin, 25 (8), 58-65. doi: http://doi.org/10.1557/mrs2000.152

14. Gallagher, D., Scanlan, F., Houriet, R., Mathieu, H. J., Ring, T. A (1993). Indium-tin oxide thin films by metal-organic decomposition. Journal of Materials Research, 8 (12), 3135-3144. doi: http://doi.org/10.1557/jmr.1993.3135

15. Gordon, R. G. (1996). Preparation and properties of transparent conductors. MRS Online Proceedings Library Archive, 426. doi: http://doi.org/10.1557/proc-426-419

16. Karthick, P., Vijayanarayanan, D., Sridharan, M., Sanjeeviraja, C., Jeyadheepan, K. (2017). Optimization of substrate temperature and characterization of tin oxide based transparent conducting thin films for application in dye-sensitized solar cells. Thin Solid Films, 631, 1-11. doi: http://doi.org/10.1016/j.tsf.2017.04.003

17. Gnesin, G. G., Skorokhod, V. V. (Eds.) (2008). Neorganicheskoe materialovedenie. Enciklopedicheskoe izdanie v 2-kh tomakh. Kyiv: Naukova Dumka, 2900.

Iatsenko Artem, PhD, Associate Professor, Departure of Chemical Technology of Ceramic and Glass, National Technical University of Ukraine «Igor Sikorsky Kyiv Polytechnic Institute», Ukraine, ORCID: http:// orcid.org/0000-0001-5292-1934,e-mail: a.yatsenko@kpi.ua

Mishchenko Anastasiia, Departure of Chemical Technology of Ceramic and Glass, National Technical University of Ukraine «Igor Sikorsky Kyiv Polytechnic Institute», Ukraine, ORCID: http://orcid.org/ 0000-0001-5993-5167, e-mail: anastasia28mischenko@gmail.com

Kornilovych Boris, Doctor of Chemical Sciences, Professor, Head of Department of Chemical Technology of Ceramic and Glass, National Technical University of Ukraine «Igor Sikorsky Kyiv Polytechnic Institute», Ukraine, ORCID: http://orcid.org/0000-0002-6393-6880, e-mail:b.kornilovych@kpi.ua 